\title{
PROBLEMS RAISED BY THE TREATMENT OF STEATORRHOEA WITH ANTIBACTERIAL DRUGS
}

\author{
J. M. French, M.D., M.R.C.P., Ph.D., D.T.M. \& H.
} Wellcome Research Wing, Department of Medicine, University of Birmingham and Queen Elizabeth Hospital, Birmingham

Coeliac disease in children, with its counterpart idiopathic steatorrhœa in adults, is one of the commonest and, perhaps, the most important of the malabsorption syndromes. Serious search for a bacterial origin for these conditions more or less ceased over 40 years ago, and for a long time they were relegated to the group of deficiency diseases. During the last decade the discovery that removal of wheat and rye gluten from the diets of ill coeliacs resulted in recovery in almost all instances has revolutionized not only the treatment and prognosis of the condition but also theoretical consideration of the mechanism of defective absorption in these patients. Developments in biopsy techniques in the last five years have allowed histological study of fresh small intestinal mucosa, and it has become apparent that in most of these cases there are abnormalities of the villi and intestinal epithelium, which might account in some measure for the malabsorption. As it is quite an easy matter to produce a malabsorptive state in a cœliac child who has recovered on a gluten-free regime simply by re-introducing gluten into the diet, considerable thought and experimental work has gone into efforts to link together malabsorption, the altered epithelial appearance and the deleterious effects of gluten.

The mechanism of the gluten effect in cœliac disease is still quite obscure; several investigators have concentrated on isolating toxic factors from wheat gluten and gliadin. Weijers and van de Kamer (1960) showed high blood glutamine values after a loading dose of gliadin; as glutamine itself was not harmful, they concluded that a glutamine-containing peptide was the injurious agent, and they thought it reached the blood from an enzymatic defect in the mucosal cells of the small intestine affecting peptide digestion. Frazer (1956) and Krainick (1958) took into account the possibility that the peptides also contained proline, and postulated a prolinase or prolidase deficiency. These suggestions are difficult to reconcile with the fact that many other proteins, casein for example, contain almost as great a proportion of glutamine and proline as gluten, yet they can be fed to cœliac children in much greater amounts than gliadin without causing trouble. Schneider, Bishop and Shaw (1960) have drawn attention to substances derived from the digestion of gluten which inhibit a peristaltic reflex of the small intestine of the rat but they found substances with a similar action in muscle and casein also. Although interesting, the relevance of these findings to cœliac disease awaits clarification. All reports on small intestinal biopsy findings in cœliac disease and idiopathic steatorrhœa draw attention to the lack of correlation between the mucosal appearance and the absorptive state, as judged by the fat excretion. It is not clear, therefore, whether the 'toxic factors', epithelial changes and malabsorption are closely related, or indeed, whether there is any direct relationship, so additional factors must still be given consideration in the production of malabsorption in these conditions. Those most deserving of study are excessive production of mucus, defective small bowel motility, defective mucosal enzymes (Dawson and Isselbacher, 1960), and abnormal gut flora. This paper is concerned only with evidence for and against the last consideration.

It is often evident in both child and adult patients with cœliac disease and tropical sprue that there is excessive fermentation in the stools. Many patients complain of excessive borborygmiasis and evil-smelling flatus, which indicate that abnormal fermentation and putrefaction are taking place within the intestinal canal. If radiographs are taken of the abdomen of such patients in the upright position, it is common to see many fluid levels with gas over them in the small intestine as well as in the colon. This excess of gas could be due to aerophagy or to a circulatory disturbance of the gut rendering it unable to remove gases, as believed by de Langen (1953). Gas production could be due to excessive fer- 
mentation of carbohydrate by intestinal bacteria. This explanation would fit in with the frothy character of the stools which is so often seen. Observations of this nature, though crude, are suggestive, in florid cases at least, that some type of abnormal bacterial fermentation within the lumen of the gut is worthy of consideration. Unfortunately the inaccessibility of the bowel, especially the small intestine, and the rapid alterations of its contents during digestion, due to changes in rates of secretion, absorption and gut motility, have made it extraordinarily difficult to characterize exactly what is taking place. In addition, there are great practical difficulties in culturing intestinal juice to obtain a true quantitative picture of the organisms in a single sample, and culturing numerous samples from different levels in the intestine at various stages of digestion presents at the moment an almost insuperable problem. Multiple examinations, however, are essential for proper evaluation, as it is well recognized that the flora varies enormously at different levels in the small and large bowel even in normal subjects. It is not surprising, therefore, that in spite of many and varied studies of the subject, no clear picture has emerged in pathological conditions. Although the direct bacteriological approach of culture of intestinal contents has tended to show that the flora in malabsorption is not different from normal, approaches to the problem from other angles, especially by the use of antibiotics, suggest that an entirely different view may eventually have to be taken. The main questions at issue are: firstly, has any substantial evidence of an abnormal gut flora in malabsorptive states ever been established, and if so, secondly, should such a floral change be regarded as primary or secondary?

As the mechanisms underlying the absorptive defect in quite a number of malabsorption syndromes are not well understood, it may serve a useful purpose to compare evidence from a condition such as cœliac disease, with what is known about tropical sprue, gastro-jejuno-colic fistula, diverticulosis of the small intestine, blind loop syndromes, Whipple's disease and even gastrectomy. What may be learnt from the study of one may be applicable in some degree to all, despite what appear to be different origins for the malabsorption.

\section{Total Weight of Bacteria in the Stool}

Some $25 \%$ or more of the dried weight of a normal stool is due to bacteria (Spencer, 1960) most of which have developed within the gut. No attempts appear to have been made to assess the weight of bacteria in malabsorption, though the dried weight of stool is greater than normal, the increase being more than would be accounted for by the excess fat alone (Comfort, Wollaeger, Taylor and Power, I953, Cooke, Thomas, Mangall and Cross, 1953, Hendry, 1960). It might be possible to decide if there was an increase in numbers of bacteria by dilution, centrifugation and nephelometry against standard bacterialo suspension (Goiffon, 1946).

\section{Specific Organisms}

After careful bacteriological study of many fæcal samples from cœliac children, Herter (1908) concluded that the condition was caused by? persistence through childhood of a bacillus which $\overrightarrow{\vec{\omega}}$ was normally present only in babyhood. This was a gram positive rod-like organism predomi--8 nant in the fæces of his coliac children, which he 3 . called $B$. infantilis. It is no longer known by this name. It is probable that he was describing. Lactobacillus acidophilus, which is often present $\mathrm{N}_{\mathrm{N}}$ in large numbers in the stools of patients withis malabsorption of various origins together with another aciduric group, $\mathrm{Cl}$. actobutylicum (iodophil음 bacteria, Goiffon, 1949). In tropical sprue, on theother hand, Ashford (1917) held the view for 3 many years that a yeast (Monilia psilosis) was responsible. Although his conclusions supported $\vec{\oplus}$ those of Kohlbrügge (190I), they have never met? with general acceptance. It is commonly believed that excessive yeasts and lactobacilli are due the presence of unabsorbed fermentable carbo $\overrightarrow{0}-$ hydrate and that they are therefore secondaryo invaders. The fermentation products of these $\frac{}{0}$ organisms could conceivably add to the sympto- $\stackrel{\circ}{\Rightarrow}$ matology by exacerbating diarrhœa for instance, but this aspect has not been studied satisfactorily. Later investigations of fæcal flora have shown no consistent picture (Mackie, Goré, and Wadia, 1928) and although it is now generally believed $\frac{3}{3}$ that neither sprue nor coliac disease is due to $a_{0}$. specific organism, the idea dies hard and it has 3 . recently been suggested on general grounds thato tropical sprue is primarily due to a virus infection§ (Manson-Bahr, 1953).

\section{Bacteriological Studies of the Upper Intestine}

An obvious approach to the study of the bacterial population of the gut is by peroral intuba- $N$ tion (Kendall, Day, Walker and Haner, 1927). N Using this technique, Olleros (1942) noted anN invasion of the stomach in tropical sprue by gram- $\sigma$ positive and gram-negative organisms, the majority of the latter being coliforms, but no significante change from normal was found in the smallos intestine in patients with tropical sprue (Milanes, Curbelo, Rodriguez, Kouri and Spies, 1946, Nadel and Gardner, 1956), or in idiopathic steatorrhœa (French, Peeney and Thompson, $\frac{\stackrel{?}{\oplus}}{\circ}$ 
BACTERIOLOGY OF INTUBATION STUDIES

IN IDIOPATHIC STEATORRHOEA (NON TROPICAL SPRUE)

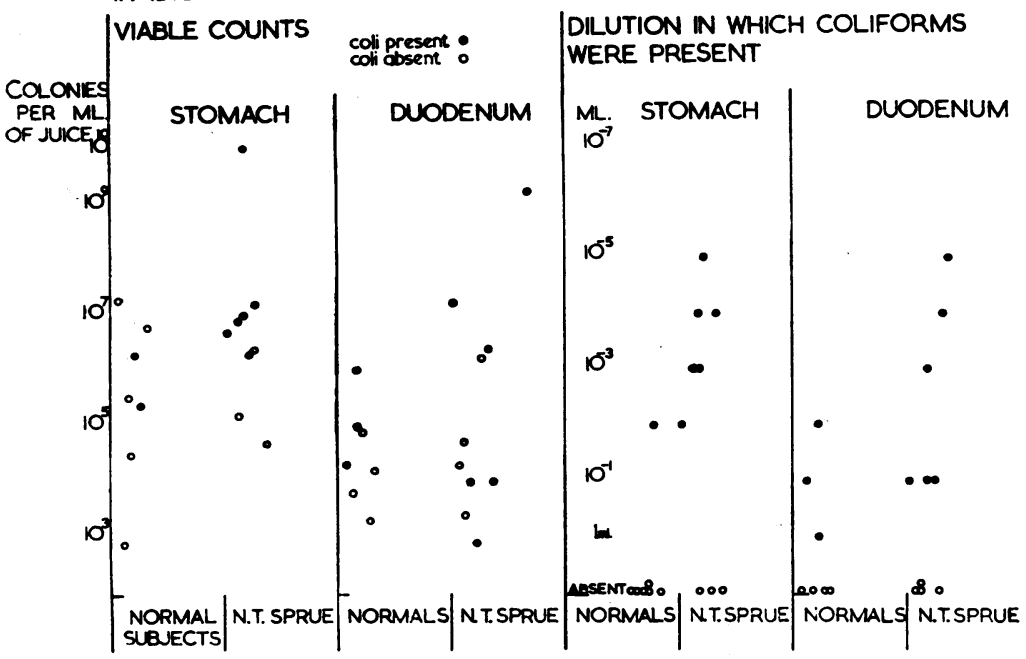

Fig. 1.-Comparison of cultures of the contents of the stomach and duodenum in normal subjects and patients with idiopathic steatorrhœe. Viable counts of four main groups only were determined, viz. coliforms, lactobacilli, enterococci, and clostridia. The results suggested that there was no significant difference between the two groups of individuals either in stomach or duodenum. No sterile cultures were encountered using an intubation technique. The patient with the highest bacterial count in stomach and duodenum ( $10^{10}$ and $10^{9}$ respectively) had bronchiectasis, with $E$. coli in the sputum. (French, Peeney and Thompson, 1949.)
1949) (Fig. I) or in cœliac disease (Anderson and Langford, 1958).

One of the main difficulties with intubation studies is contamination of the tube by mouth organisms. This has been overcome to some extent by occluding the distal holes with latex, sterilising the tube, and disrupting the latex with a syringe full of air when the tube is in position in the intestine (French, Peeney and Thompson, 1949). An alternative technique adopted by others disregards organisms which can also be cultured from the mouth as 'transient' intestinal flora and therefore of no significance. Whether this is a valid assumption in the presence of malabsorption is another matter. Baker and Achaya (r96r) adopting the method of Cregan and Hayward (1953) needled the intestine at laparotomy in three cases of tropical sprue; cultures of the fluid obtained were sterile. In general it may be said that as far as the present experimental work has gone, no gross and possibly no significant contamination of the upper small intestine with fæcal organisms has been demonstrated in these malabsorptive states. One important omission in the experimental work to date must be noted however. All the studies mentioned here dealt with patients in a fasting state, when the cleansing effects of gastric acidity, peristaltic movements of the gut towards the colon and the absence of food would give the least favourable conditions for retention or survival of any colonies of bacteria within the lumen of the small intestine; but conditions during feeding may be quite different. Coliforms, in ideal conditions, divide once every ${ }_{15}$ minutes or so. If the nutrient medium is absorbed in normal subjects, say, for the sake of argument, in half an hour, one coliform might divide to become four, but if the same absorption process took 4 hours, as it might well do in malabsorption (Crane and Neuberger, 1960) then one coliform might divide to become 60,000 organisms. The really significant experiments might well lie in a series of studies designed to elucidate what happens to the growth of bacterial flora throughout a 24-hours period. The complexity of such a procedure is formidable but an interesting finding has been recorded by Anderson and Langford (1958), who observed gross contamination by fæcal flora if the tube was allowed to lie within the intestine for 24 hours, after fasting studies had shown a normal flora. They were uncertain whether this represented growth within the tube or within the gut. Until some studies of this nature have been carried out, it would be unwise to conclude that the small intestinal flora after feeding in the presence of malabsorption is necessarily normal, since at present the only available evidence has been derived from subjects in a fasting state.

\section{Influence of Antibiotics on Diarrhoea and Steatorrhcea}

If intestinal bacteria play some part in the malabsorption syndromes, their influence could be studied retrospectively by an examination of the effect of their elimination by antibiotic drugs. Unfortunately, even with the large array of antibiotics effective in suppressing intestinal organisms, no single drug, or combination of drugs has been shown to eliminate all organisms (Kirsner, Levin and Palmer, 1952). The removal of a 
sensitive species quickly results in an overgrowth of insensitive bacteria and yeasts. The complex bacterial changes which take place in the intestinal tract during antibiotic therapy have not yet been studied extensively in malabsorption states. Nevertheless, several studies already indicate that antibiotics may have a great influence on the bacterial population and that malabsorption has been cured and induced by antibacterial drugs.

In tropical sprue, seven patients were cured after a course of combined drugs (French, Gaddie and Smith, 1956), and this effect was confirmed by Caroli, Le Quintrec and Reboul (1957). Similar courses of antibiotics were used by Baker (1957) in a few patients with sprue in India. Some appeared to show lasting improvement but in others little or no improvement was noted. A third group improved as judged by the fat balance during the course of chemotherapy, but they relapsed later. The cure of a case of 'indigenous' sprue with chloromycetin followed by aureomycin was described by Renner (1952). In 15 patients with idiopathic steatorrhœa resistant to a gluten-free diet we have tried chemotherapy in addition to the diet (Crane and French, 196r). In six of these, no change took place in the absorptive state, as judged by the fat excretion. In four, fat absorption became normal within a few days, though in one of them steatorrhœa returned a week after stopping the drugs (Fig. 2); one made a striking clinical improvement but no fat studies were done; in four the diarrhœa and steatorrhœa were greatly increased. In two of the latter group, diarrhoa increased almost to choleraic proportions and the drugs had to be stopped. Bacteriological studies provided no evidence that the increase in diarrhoea was staphylococcal in origin. Wirts and Goldstein (1960) reported a patient cured with neomycin. In coliac disease, we have seen no significant changes in fat absorption in several children treated with antibiotics. In Whipple's disease, the abatement or disappearance of diarrhœa and steatorrhœa has been noted after chloramphenicol (Paulley, 1952), chlortetracycline (Schaffner and Scherbel, I955), sulphasalazine (Haex and van Beek, 1955, Kooreman, 1957), and tetracycline (England, French and Rawson, 1960). In diverticulosis of the small intestine, diarrhœa disappeared after therapy with one or other of the tetracyclines (Dick, 1955, Badenoch, Bedford and Evans, 1955, Blachford and Dawson, 1956, Gellman, 1956). Although steatorrhœa was proved to be present in these patients, no observations were made of the effect of the antibiotics on fat absorption, but Watkinson, Feather, Marson and Dossett (1959) showed that steatorrhœa disappeared with tetracycline therapy in their patient, and we have observed the same in one

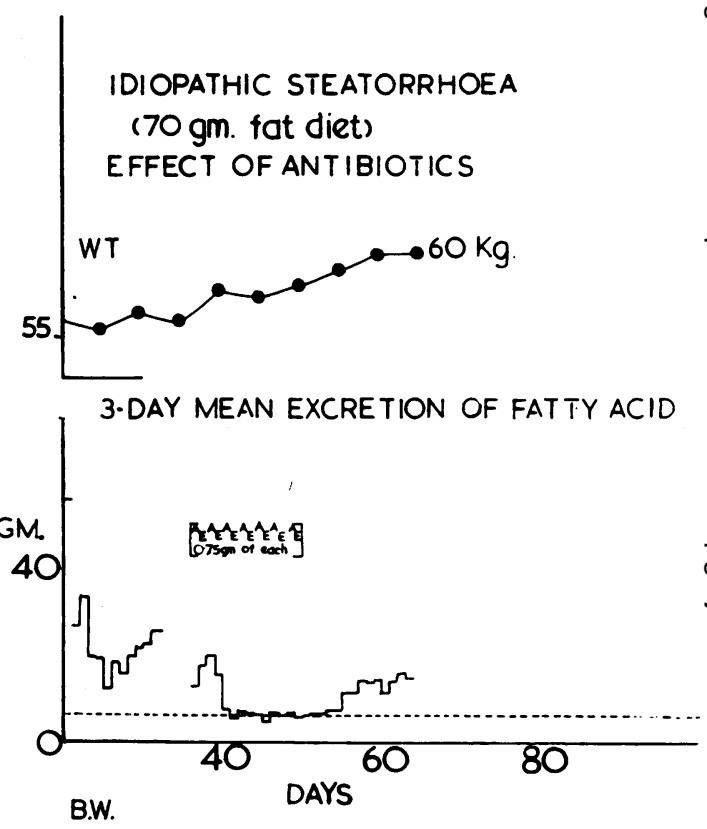

FIG. 2.-Fat excretion during antibiotic therapy in a $\vec{z}$ patient with idiopathic steatorrhœa of thirty years duration, who had been having a gluten-free diet for a year previously with only slight improvement $\overrightarrow{0}$ During the course of antibiotics (aureomycin and erythromycin) fat excretion became normal, but. increased again some days after stopping the drugs

patient (French and Hawkins, 196r). In several patients with malabsorption after partial gas- $\frac{\circ}{\varnothing}$ trectomy, in whom there was afferent loop stasis, oral antibiotics cured the steatorrhœa (Kinsella, $\overrightarrow{\overrightarrow{0}}$ Hennessy and George, 1960, Goldstein, Wirts and Kramer, 1961). In gastro-colic fistula, few now believe that the steatorrhœa is due to a bypassing of the small intestine, as assumed by Bennett and Hardwick (1940) in their concept of ileo-jejunal insufficiency. It seems most likely that the seepage of fæcal bacteria from the colon into the upper small intestine results in a jejunoileitis', a mild inflammatory process from unspecified toxic products of bacterial metabolism. There is no suggestion that any specific bacteria $\frac{T}{O}$ are involved, yet the steatorrhœa is always a severe one, and patients usually go downhill very rapidly. $N$ Mere diversion of the fæcal stream by colostomy $N$ may improve their nutrition enormously before repair of the fistula is undertaken. In two patients $\omega$ with gastro-colic fistula, we have noted a shortlived improvement of fat absorption with anti- $\stackrel{0}{C}$

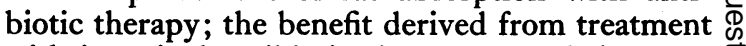
with intestinal antibiotics is now regarded as one of the mainstays of pre-operative preparation (Kay, I960). In a patient with blind-loop syndrome, neomycin cured the steatorrhœa, though 
it returned gradually afterwards (Kay, 1960). It may well be that the rare cases of post-gastrectomy steatorrhœa which respond to antibiotics are instances of blind-loop syndrome analagous to those in the lower gut (Goldstein et al, 196r). Apart from our own group of four patients with adult cœliac disease whose steatorrhœa was made much worse, all these studies record improvement of absorption with antibiotics.

On the other hand, there is evidence that antibiotics can induce steatorrhœa. It is well recognized that when given orally they may cause diarrhœa. This is loosely attributed to the irritant effect of the drug, changes in intestinal bacteria or growth of yeasts. Sometimes the intestinal upsets persist for weeks or months after withdrawal of the drugs. Little attempt has been made to define this common disorder, but Merliss and Hoffman (I95I) described several patients with a steatorrhoea syndrome which developed after antibiotic therapy. Recently, there have been several reports of a more clearly defined malabsorptive state, including changes in the intestinal villi, induced by large doses of neomycin (Jacobson, Chodos and Faloon, 1960). Although in the disorder described by Merliss and Hoffman, a floral change within the intestine seems the most likely explanation, in the neomycin-induced syndrome the doses used were so large (12 gm. daily) that a direct toxic effect upon the intestinal epithelium or enzyme systems must also be considered.

It is clear from this survey that antibiotics may either ameliorate or worsen malabsorption; it may also actually induce it in previously normal subjects. Although there are few supporting bacteriological studies, it is likely that the changes are related closely to alterations in the intestinal flora. In all the pathological states described, the intestine is altered in such a way that bacteria might be expected to proliferate in abnormal numbers, though it is not yet proved that they in fact do so. The range of antibacterial drugs is so wide that it seems most unlikely that the changes could be due wholly to specific metabolic effects of the drugs themselves but this cannot yet be disregarded. One of the most instructive reports as to the role of bacteria is provided by the work of Watkinson et al (1959) in a patient with diverticulosis of the small intestine. Antibiotic therapy cured the steatorrhœea so long as the drug was given. The bacteria cultured from the diverticula were normal intestinal inhabitants. When the worst-affected area was resected, steatorrhœa disappeared, despite shortening of the intestine from the removal of $70 \mathrm{~cm}$. of jejunum. This strongly suggests that the steatorrhœa was due to seeding of the upper intestinal contents with bacteria from areas of stasis in the diverticula. A similar idea would explain the disorders encountered in gastro-colic fistula, blind loops and some cases of post-gastrectomy steatorrhœa. In gastrectomy patients, Goldstein et al (196r) were able to show that the good response to antibiotics was in those with an abnormally high bacterial count in the afferent loop juice. The anastomoses were antiperistaltic, the loops were long, and there was achlorhydria, all conditions favouring the growth of organisms naturally occurring in the gut. Where there is no isolated source of seeding, as in sprue, adult cœliac disease and other conditions such as Whipple's disease and systemic sclerosis, delay in absorption with poor motility of the small intestine might result in an analagous situation, in which the presence of only a few normal bacteria would suffice, but they would have an unusually long period in a medium enriched by the unabsorbed products of digestion, in which they could grow readily. Their role in all these states could be regarded as secondary in the sense that some other condition was necessary before they could cause steatorrhœa. One remarkable feature that needs consideration is that in all those instances in which a source of bacterial seeding of the intestine could be identified, only normal intestinal organisms were grown on culture, and the same would, no doubt, apply in the case of gastro-colic fistula, one of the most severe forms of malabsorption. How does it come about that normal organisms in their usual. habitat can give rise to such a severe upset? It does not seem likely that their mere presence would cause malabsorption, as might Giardia lamblia, for instance, applied to the duodenal and jejunal walls. It seems more reasonable to suppose that the malabsorption is due to some effect of their products of metabolism, or dissolution, and although these might be complex toxins, they could equally be quite simple substances, such as amines, or organic acids. It is possible that the key to this situation is their rapid growth in the presence of food, and that there is no heavy bacterial contamination until food is actually present. In this respect, an interesting analogy in veterinary medicine is worth recounting; enterotoxæmia of sheep is a highly fatal condition caused simply by abruptly feeding wheat to animals used to a hay diet (Bullen and Scarisbrick, 1957). The unusual flow of starch into the small intestine is followed by an intense fermentation by Streptococcus bovis and the animals die in acute acidosis, with blood $\mathrm{pH}$ as low as 6.6 , from the absorption of large amounts of organic acids; if they survive this, they may succumb from toxæmia from the development of enormous numbers of clostridia within the intestine. The organic acids may play a further part by making the mucosal walls more 
permeable to toxic materials ordinarily retained in the lumen. The amount of wheat fed is critical. If it is introduced into the diet gradually, no toxæmia ensues, as the bacteria of the rumen, an organ tolerant of acid fermentation, then have time to change slowly to amylolytic types. The acids, streptococci, clostridia and their toxins are present normally in the sheep, but in smaller quantities, and the toxæmia from fermentation within the small intestine appears to be due not so much to the type of flora as to its rapidly growing nature, a conception well borne out by the work of Jenkin and Rowley (1959).

From the report of Merliss and Hoffman (195I), it still seems possible that bacteria could also be a primary cause of malabsorption. If it is assumed that their patients had normal small intestines prior to the course of antibiotics, steatorrhœa must have resulted simply from a change of flora, provided it can also be assumed that injury to the mucosa was not part of the antibiotic action. Malabsorption persisting for some months following acute infective enteritis has recently been noted by King and Joske (1960) and Crismer, Drèze and Demelenne-Jaminon (1959) reported steatorrhœa from enteritis due to Proteus hauseri cured by neomycin. These observations might have a bearing on the etiology of tropical sprue. It is fully recognized that the types of bacteria predominating in the intestine depend almost entirely on the kind of food ingested and residues at various levels. It might well be that in some areas of the tropics, the type of diet or presence of some special dietary constituent is all-important for the initiation of tropical sprue, in that it leads to the establishment of a type of flora which gradually injures the mucosa. Once malabsorption has begun it is easily maintained by normal intestinal organisms. There seems no good reason to believe that tropical sprue is primarily due to vitamin deficiencies as it is well recognized that many sprue patients have had an excellent diet at the time of onset of their illness (French, Gaddie and Smith, 1956).

The anomaly of malabsorption being both created and cured by antibiotics need not be taken as evidence against the general thesis that the alterations are due to floral changes. At present, the impossibility of sterilizing the intestinal tract by any drug and the difficulties involved in tracing bacterial changes during such therapy have prevented a proper day-to-day evaluation which might explain these apparent inconsistencies.

\section{Influence of Antibiotics on the Absorption and Excretion of Materials Other than Fat and Water}

The prominence of the fatty nature of the stools of patients with malabsorption, and the ease with which fat is recovered and measured chemically have tended to obscure the importance of measuring other excreted products. Some attention has been paid to nitrogen, but no reports have been made of the influence of antibiotics on nitrogen excretion in these conditions.

The pallor of the stools is mainly due to alterations in the type of bile pigment in the fæces. When antibiotics are given, the stools undergo changes in colour which differ according to the antibiotic used. In tropical sprue stercobilin and stercobilinogen are reduced in amount and bilirubin and biliverdin are increased (French, Gaddie and Smith, 1956). There is little doubt that these changes are the result of alterations in flora induced by the drugs, and parallel those seen in normal subjects (Sborov, Jay and Watson, r95 I, Goiffon and Goiffon, I954). After cessation of tetracycline therapy, stercobilin (tetrahydromesobilene, b) returns to colour the fæces, but urobilin (mesobilene, b) returns largely as d-urobilin, instead of the normal i-urobilin (Sborov et al, 1951, Gray and Nicholson, 1958). D-urobilin, which tautomerizes readily to a mesobiliviolin, may be excreted for months after withdrawal of tetracycline. This explains the deepviolet colour of processed stool extracts sometimes seen after tetracycline has been used, and indicates that long after the immediate influence of the drug has gone, some floral change persists, the nature of which is quite unknown. Increased fæcal porphyrins have been reported in 'sprue' by Vanotti (1954) and in a man with Whipple's disease (England, French and Rawson, 1960). During treatment of this patient with chlortetracycline for his steatorrhœa, the amounts of fæcal porphyrins were strikingly reduced, indicating that they were probably largely of bacterial origin. At the same time, a chronic sunlightsensitive dermatitis faded rapidly, having failed to respond to nicotinic acid given during a twomonth period beforehand. This observation suggests that the pellagroid dermatitis sometimes seen in malabsorption is due to the presence of abnormal amounts of porphyrins and not to nicotinic acid deficiency as usually thought. It also re-opens the question of the origin of the sunlight dermatitis in true pellagra. In a number of patients with steatorrhœa of the adult cœliac type, fæcal porphyrins were found to be greatly increased, both copro- and protoporphyrin being in excess; frequently other porphyrins (deuteroand meso-) were present in the fæces in abnormal quantities also, but total daily excretion in the urine was normal (England and French, 196r). Indican, indigoid pigments and other indole and skatole derivatives may be found in excess in the 
URINARY INDICAN

EFFECT OF ANTIBIOTICS

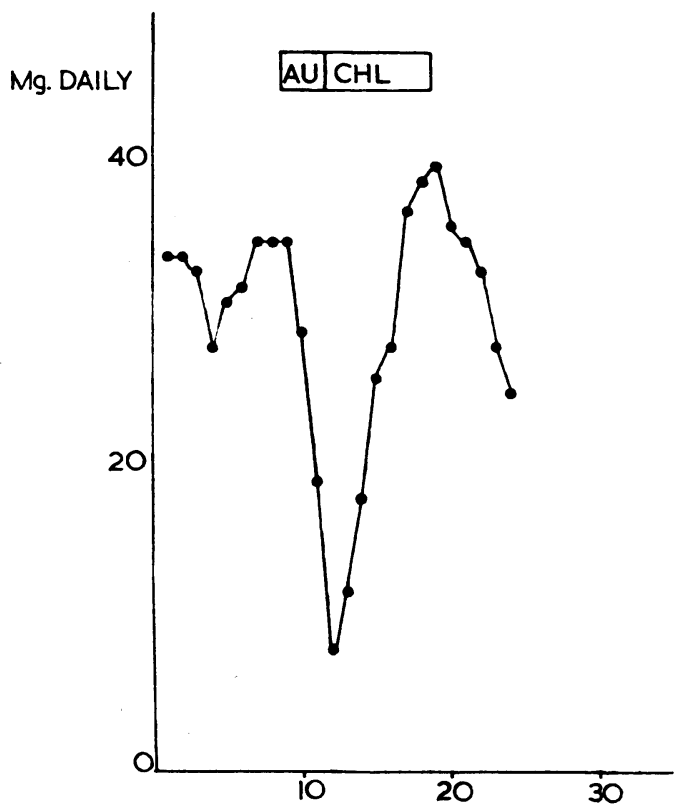

DAYS

FIG. 3.-Urinary indican in a patient with idiopathic steatorrhœa, during treatment with aureomycin and chloromycetin. There was a striking decrease with aureomycin followed by an increase with the second drug.

urine (Rimington, 1946, Horning and Dalgliesh, 1958). The amounts may be reduced by antibiotics (Fig. 3), denoting their bacterial origin, and they are therefore probably to be found in excess in the fæces. Important pharmacological effects in sprue have been attributed to the porphyrins (Vanotti, 1954) and to the skatoles (Horning and Dalgliesh, 1958). In a study of patients with idiopathic steatorrhœa, Boscott and Cooke (1954) reported an excess of $p$-hydroxyphenylacetic acid in the urine and attributed this to an upset in the tyrosine metabolism due to a lack of ascorbic acid. Attention was first drawn to this excessive excretion (as oxyphenylacetic acid) by Herter (1908) in coeliac disease, and attributed by him to excessive bacterial action in the gut. Study of the excretion before and during antibiotic therapy would settle which of these views is correct.

\section{Vitamins}

Patients with severe malabsorption may show manifestations of vitamin deficiency of almost any type. This may be due to simple malabsorption of the vitamin concerned, as seems likely in the case of folic acid and the fat soluble vitamins, for instance, or to some more subtle form of malabsorption, as in the destruction, deviation, or failure to synthesize by intestinal organisms. Only in the case of vitamin $B_{12}$ so far has there been evidence offered on these points. A rise of reticulocyte count with subsequent hæmatological improvement after antibiotic courses in a patient with a cul-de-sac of the small intestine was noted by Naish and Capper (1953) and similar observations have been reported since in other steatorrhoeas. This has suggested that bacteria take up vitamin $B_{12}$ to the detriment of the host and this interpretation has been confirmed in a number of instances by improved absorption of radioactive cyanocobalamin after antibiotics in diverticulosis, blind loop syndromes and tropical sprue (Badenoch et al, 1955, Gellman, 1956, Halsted, Swendseid, Lewis and Gasster, 1956, Mollin, Booth and Baker, 1957, Scudamore, Hagedorn, Wollaeger and Owen, 1958, Badenoch, 1960, Doig and Girdwood, 1960) though there is little or no improvement in idiopathic steatorrhoea. The choice of antibiotic was important; tetracyclines were effective whilst neomycin was not (Halsted et al, 1956).

It has been suggested by Badenoch (1960) that vitamin $\mathrm{K}$ deficiency might be precipitated by antibiotic therapy. In I95I, we studied a patient with idiopathic steatorrhoea who was given a sixo weeks' course of succinylsulphathiazole in normal daily therapeutic dosage. Within a few days of stopping the drug, she developed hæmorrhagic effusions in skin, muscles and joints, and her hæmoglobin fell from $90 \%$ to $40 \%$. She had not previously shown any hæmorrhagic tendency, though this has been described in steatorrhoea in a number of instances. Her prothrombin activity at the time of the onset of her hæmorrhagic condition was estimated as nearly zero. Twenty-four hours after administration of vitamin $\mathrm{K}$ intramuscularly, it was $67 \%$ and the following day $100 \%$. This seemed clearly a case where the sulphonamide drug had interfered with bacterial synthesis of vitamin $\mathrm{K}$ in the gut.

\section{Summary}

I. It may be concluded that over the past few years evidence has steadily accumulated which indicates that bacteria play an important part in the symptomatology of many of the malabsorption syndromes. Owing to the technical difficulties of the bacteriological approach to the problem, their role up till now has largely been regarded as secondary.

2. Many bacterial metabolites are present in excess in the urine and fæces of patients 
with these conditions, and, apart from the possibility of cure, antibiotics offer an excellent weapon for attacking problems connected with their formation, excretion and pharmacological importance.

3. They may also be used to study the formation, absorption or destruction of vitamins and other materials by intestinal bacteria.

4. Study of patients with malabsorption by antibiotics has produced increasing evidence that bacteria play more than just a secondary role in the production of symptoms, and in some cases they appear to play an integral part in the mechanism by which malabsorption is maintained. It may in time be shown that intestinal bacteria play a primary role in the causation of some of the syndromes.

5. From the therapeutic point of view antibiotics have curative value in some instances, but cause deterioration in others. More extensive study of their action should disclose the reasons underlying this discrepancy.

I wish to acknowledge the unstinted support and help of Professor W. Melville Arnott. I am grateful to the United Birmingham Hospitals Endowment Fund, the Stag Charitable Trust (Watney Mann Ltd.) and the Medical Research Council for financial assistance.

\section{REFERENCES}

Anderson, C. M. and Langford, R. F. (1958): Bacterial Content of Small Intestine of Children in Health, in Cœliac Disease, and in Fibrocystic Disease of the Pancreas, Brit. med. $\mathcal{F}$., i, 803.

AshroRD, B. K. (1917): The Etiology of Sprue, Amer. F. med. Sci., I54, 157.

BADENOCH, J. (1960): Steatorrhœea in the Adult, Brit. med. Y., ii, 879.

, BedFord, P. D., and Evans, J. R. (1955): Massive Diverticulosis of the Small Intestine with Steatorrhœa and Megaloblastic Anæmia, Quart. J. Med., 24, 321.

BAKER, S. J. (1957): Idiopathic Tropical Steatorrhœa, Indian Y. med. Sci., rx, 687.

- and ACHAYA, K. (196I): To be published.

BennetT, T. I. and HaRDWICK, C. (1940): Chronic Jejuno-ileal Insufficiency, Lancet, ii, 38r.

Blachford, R. D. and Dawson, D. W. (1956): Association of Jejunal Diverticulosis with Macrocytic Anæmia, Brifo med. $\mathcal{F} ., \mathrm{i}, 1407$.

BoscotT, R. J. and Cooke, W. T. (1954): Ascorbic Acid Requirements and Urinary Excretion of p-Hydroxyphenylacetic Acid in Steatorrhœa and Macrocytic Anæmia, Quart. $\mathscr{Y}$. Med., 23, 307.

Bullen, J. J. and Scarisbrick, R. (1957): Enterotoxæmia of Sheep. Experimental Reproduction of the Disease, Y. Patk. Bact., 73, 495.

Caroli, J., Le Quintrec and Reboul (1957): Le Traitement des Steatorrhées Eventuellement Compliqués de Steatose Massive du Foie par les Antibiotiques, Arch. Mal. Appar. dig., 46, 6r3.

Comfort, M. W., Wollaeger, E. E., TAYlor, A. B., and Power, M. H. (1953): Non-tropical Sprue: Observations on Absorption and Metabolism, Gastroenterology, 23, 155.

Cooke, W. T., Thomas, G., Mangall, D., and Cross, H. (1953): Observations on the Fæcal Excretion of Total Solids, Nitrogen, Sodium, Potassium, Water and Fat in the Steatorrhœa Syndrome, Clin. Sci., $12,223$.

Crane, C. W. and French, J. M. (196r): To be published.

and Neuberger, A. (1960): Absorption of ${ }^{15} \mathrm{~N}$ Labelled Yeast Protein in Adult Coliac Disease, Brit. med. F., ii, 81 5 .

Cregan, J. and Hayward, N. J. (1953): The Bacterial Content of the Healthy Human Small Intestine, Brit. med. $\mathscr{J}$., i, 1356.

Crismer, R., Drèze, C., and Demelenne-Jaminon, G. (1959): Guérison par la Néomycine d'une Steatorrhée Associée a une Entérite à Proteus Hauseri: Relation des Steatorrhées Infectieuses avec la Sprue Nostras, Acta gastroent. belg., 22, 47.

Dawson, A. M. and Isselbacher, K. J. (1960): The Esterification of Palmitate - I-C ${ }^{14}$ by Homogenates of Intestinal Mucosa, Y. clin. Invest., 39, 150.

De LANGen, C. D. (1953): Steatorrhoea and the Intestinal Circulation, Acta med. scand., r46, 7.

Dick, A. P. (1955): Association of Jejunal Diverticulosis and Steatorrhcea, Brit. med. $\boldsymbol{F}$., i, 145 .

Doig, A., and GirDwood, R. H. (1960): The Absorption of Folic Acid and Labelled Cyanocobalamin in Intestinal Malabsorption, Quart. F. Med., 29, 333.

England, M. T. and French, J. M. (196r): To be published.

,-- and Rawson, A. B. (1960): Antibiotic Control of Diarrhœa in Whipple's Disease, Gastroenterology, $39,219$.

Frazer, A. C. (1956): On the Growth Defect in Coliac Disease, Proc. Roy. soc. Med., 49, roog.

French, J. M., GAdDie, R., and Smith, N. M. (1956): Tropical Sprue. A Study of Seven Cases and their Response to Combined Chemotherapy, Quart. F. Med., 25, 333.

- and Hawkins, C. F. (196I): Unpublished data.

, Peeney, A. L. P., and Thompson, M. D. (1949): Unpublished data.

Grilman, D. D. (1956): Diverticulosis of the Small Intestine with Steatorrhcea and Megaloblastic Anæmia, Lancet, ii, 873.

Golffon, R. (1946): Appréciation de la Quantité de Microbes Contenus dans les Selles, Arch. Mal. Appar. dig., 35, 462. (1949): Manuel de Coprologie Clinique, 5th Edn. Paris: Masson.

and Golfron, B. (1954): Signes Coprologiques des Diarrhées par Ántibiotiques, Presse méd., $23,488$.

GoldsteIn, R., Wirts, C. W., and KRAMER, S. (1961): The Relation of Afferent Limb Stasis and Bacterial Flora to the Production of Post-gastrectomy Steatorrhœa, Gastroenterology, 40, 47. 
Gray, C. H. and Nicholson. D. C. (1958): The Chemistry of the Bile Pigments. The Structures of Stercobilin and d-Urobilin, F. chem. Soc., 3, 3085 .

HAEx, A. J. C. and van BEEK, C. (I955): Behandeling van de Ziekte van Whipple met Chemotherapie en Antibiotica, Ned. T. Geneesk. 99, 2770.

Halsted, J. A., Swendseid, M. E., Lewis P. M., and Gasster, M., (1956): Mechanisms Involved in the Development of Vitamin $\mathrm{B}_{12}$ Deficiency, Gastroenterology, 30, 21.

Hendry, E. B. (1960): The Chemical Diagnosis of Steatorrhœa, Brit. med. F., ii, 975.

HeRTER, C. A. (1908): On Infantilism from Chronic Intestinal Infection. New York: Macmillan.

Horning, E. C. and Dalgliesh, C. E. (1958): The Association of Skatole-forming Bacteria in the Small Intestine with Malabsorption Syndrome and Certain Anæmias, Biochem. $\mathcal{F}$., 70, 13 P.

Jacobson, E. D., Chodos, R. B., and Faloon, W. W. (1960): An Experimental Malabsorption Syndrome Induced by Neomycin, Amer. F. Med., 28, 524.

Jenkin, C. R. and Rowley, D. (I959): Possible Factors in the Pathogenesis of Cholera, Brit. F. exp. Path., 40, 474.

KAY, A. W. (1960): Surgical Aspects of the Malabsorption Syndrome, Brit. med. $\mathcal{Y}$., i, 1291.

Kendall, A. I., Day, A. A., WALKer, A. W., and HANER, R. C. (1927): The Bacteriology and Chemistry of Adult Duodenal Contents, $\mathcal{Y}$. infect. Dis., 40, 677.

KING, M. J. and Joske, R. A. (1960): Acute Enteritis with Temporary Intestinal Malabsorption, Brit. med. f., i, 1324.

Kinsella, V. J., HenNessy, W. B., and George, E. P. (1960): A Study on Post-gastrectomy Malabsorption, Gut, 1, 372.

Kirsner, J. B., Levin, E., and Palmer, W. (1952): Use of Antibiotics in Gastrointestinal Diseases, A.M.A. Arch. intern. Med., 90, 677.

KohlBRÜGGE, J. H. F. (190I): Een Bijdrage tot de Aetiologie der Indische Spruw (Psilosis), Ned. T. Geneesk., 37 ii, 88 r.

Kooreman, P. J. (1957): De Ziekte van Whipple (discussion), Ned. T. Geneesk., ror, 2254.

KRAINICK, H. G. (1958): Weitere Untersuchungen über den Schädlichen Weizenmehleffekt bei der Cöliakie I, Helv. padiat. Acta, 13, 432.

MACKIE, F. P., GoRE, S. N., and Wadia, J. H. (1928): The Bacteriology of Sprue, Indian F. med. Res., 16, 95.

Manson-BaHR, P. (1953): The Causation of Tropical Sprue, Lancet, ii, 389.

MerLiss, R. H. and HoFFMAN, A. (195 I): Steatorrhoea following the Use of Antibiotics, New Engl. Y. Med., $245,328$.

Milanes, F., Curbelo, A., Rodriguez, A., Kouri, P., and SpIes, T. D. (1946): A Note on Bacteriological and Parasitic Studies of the Intestinal Contents of Patients with Sprue, Gastroenterology, 7, 306.

Mollin, D. L., Booth, C. C., and BAKER, S. J. (1957): The Absorption of Vitamin B 12 in Control Subjects in Addisonian Pernicious Anæmia and in the Malabsorption Syndrome, Brit. F. Hamat., 3, 412.

Nadel, H. and Gardner, F. H. (1956): Bacteriological Assay of Small Bowel Secretion in Tropical Sprue, Amer. $\mathcal{J}$. trop. Med., 5, 686.

NAISH, J. and CAPPER, W. M. (1953): Intestinal cul-de-sac Phenomena in Man Lancet, ii, 597.

Olleros, A. R. (1942): Gastric Similarities and Differences between Tropical Sprue and Pernicious Anæmia, Amer. F. dig. Dis., 9, 261 .

PaulleY, J. W. (1952): A Case of Whipple's Disease (Intestinal Lipodystrophy), Gastroenterology, 22, 128.

RENNER, vON DIETER (1952): Erfolgreiche Aureomycin Behandlung bei Einheimischer Sprue, Med. Klin., 47, 1659.

Rimington, C. (1946): Indigoid Pigments derived from a Pathological Urine, Biochem, $\mathcal{Y}$,, 40, 669 .

SBOROV, V. M., JAY, A. R., and WATSON, C. J. (1951): The Effect of Aureomycin on Urobilinogen Formation and the Fæcal Flora, . Lab. clin. Med., 37, 52.

SchAFFNER, F. and Scherbel, A. L. (1955): Whipple's Disease, Gastroenterology 29, rog.

SchNeIDER, R., Bishop, H., and SHAw, B. (1960): The Inhibition of the Peristaltic Reflex by Substances from Protein Sources, Brit. Y. Pharmacol., 15, 219.

Scudamore, H. H., HAGEDORN, A. B., Wollaeger, E. E., and Owen, C. A. (1958): Diverticulosis of the Small Intestine and Macrocytic Anæmia: Absorption of Radioactive $\mathrm{B}_{12}$, Gastroenterology 34, 66.

SPENCER, R. P. (1960): The Intestinal Tract. Springfield, Illinois: Charles Thomas.

VANOTTI, A. (1954): Porphyrins. London: Hilger and Watts.

WATKInSON, G., FEATHER, D. B., MARSON, F. G. W., and Dossetr, J. A. (1959): Massive Jejunal Diverticulosis with Steatorrhœa and Megaloblastic Anæmia Improved by Excision of Diverticula, Brit. med. Ү. ii, 58.

Weijers, A. A. and KAMER, J. H. vAN DE (1960): Celiac Disease and Wheat Sensitivity, Pediatrics, $25,127$.

Wirts, C. W. and Goldstein, F. (1960): Effect of Antibiotic Therapy in a Probable Case of Non-tropi-al Sprue. Gastroenterolıgy, 39, 628. 